\title{
Provenance Experiments with Baldcypress, Live Oak, and Sycamore Illustrate the Potential for Selecting More Sustainable Urban Trees
}

\author{
Michael A. Arnold, Donita L. Bryan, Raul I. Cabrera, Geoffrey C. Denny, Jason J. Griffin, Jeffery K. \\ lles, Andrew R. King, Gary W. Knox, Leonardo Lombardini, Garry V. McDonald, Cynthia B. McKen- \\ ney, D. Thayne Montague, Genhua Niu, H. Brent Pemberton, Adam L. Purnell, Larry J. Shoemake, \\ Daniel K. Struve, and W. Todd Watson
}

\begin{abstract}
Ecotypic, clonal, and racial variation present in tree species across their native ranges represent a largely untapped opportunity to select superior seed sources or clonal materials to withstand a variety of unique environmental stresses imposed in built environments and managed landscapes. This paper focuses on three important woody plant genera (Quercus L., Platanus L., and Taxodium Rich.) and researchers' efforts to discover superior genotypes with tolerances to environmental stresses, including alkaline soil conditions, moisture deficits, and temperature extremes. The study authors are also interested in exploiting geographic provenances and open-pollinated family selection to identify unique genotypes or populations having desirable ornamental attributes, rapid root regeneration potential, and/or desirable plant architecture. A discussion of current results, potential impacts on selection of urban forest trees for managed landscapes, and plans for future development and research are presented.

Key Words. Built Environments; Managed Landscapes; Platanus occidentalis; Quercus fusiformis; Quercus virginiana; Seed Source; Taxodium distichum; Urban Trees.
\end{abstract}

Attention to the provenance (genetic origin of seed sources) has long been popular in forestry breeding programs, culminating in the extensive breeding efforts with southern pines (Pinus taeda $\mathrm{L}$. and its relatives) and other conifers in the western United States for a variety of silvicultural traits (Zobel and Talbert 1984). Subsequently, forestry programs using non-native species in tropical regions to augment or replace the cutting of native rainforests have received attention (Zobel et al. 1987). Many nursery professionals recognize the concept of seed source (location of seed collection), but few recognize the distinction of seed source from provenance (Arnold 2011). Provenance work for urban forest trees began as early as the 1960s (Kriebel and Wang 1962) and 1970s (Townsend 1977), but has seldom been attempted through large scale cooperative efforts as with species grown for commercial forestry (Struve 1982). Tree taxa in which provenance was researched for traits from a horticultural or aboricultural perspective, included some species of Acer L. (Kriebel and Wang 1962; Townsend 1977; Townsend 1983; Ware 1983; Pair 1994; Sibley et al. 1995; Graves 1996; Sibley et al. 1997; Zwack et al. 1998; St. Hillaire and Graves 2001; Bsoul et al. 2007), Quercus L. (Struve and McKeand 1994; Pounders et al. 2004; Struve et al. 2006; Purnell 2010), Picea pungens Engelm. (Houston 1988), Alnus maritima (Marsh.) Muhl. ex Nutt. (Schrader and Graves 2000), Maackia amurensis Rupr. \& Maxim. (Pai and Graves 1995), Ulmus L. (Guries and Smalley 1990), and Platanus occidentalis L. (Shoemake 1996; Shoemake and
Arnold 1997; Shoemake et al. 2004). This initial work was often conducted using taxa traditionally propagated from seed and thus was limited to gains in breeding/selection cycles associated with narrow sense heritability (variation associated with additive genetic effects). With advances in vegetative propagation of some traditionally seedling grown taxa, for instance Taxodium (Zhou 2005; King 2010; King et al. 2011), it may also be feasible to capitalize on gains from broad sense heritability (gains associated with both additive and non-additive genetic variance).

The purpose of this paper is to use results from selected studies on three important North American native landscape tree genera (Taxodium, Quercus, and Platanus) to illustrate the potential to improve aesthetic traits and cultural characteristics of trees for built environments in urban and suburban landscapes.

\section{MATERIALS AND METHODS}

Three series of studies are highlighted as examples of the potential to use provenance selection and evaluations to enhance urban tree performance for a variety of growth, stress responses, disease resistance, and ornamental characteristics.

\section{Taxodium distichum Studies}

Provenances of Taxodium distichum var. distichum (TD) and $T$. $d$. var. imbricarium from eastern Texas, U.S., to the Florida panhandle (northwestern Florida) (Eastern Provenances, EP), transi- 
tional $T . d$. var. distichum from the central Texas (TX), and $T . d$. var. mexicanum (Montezuma cypress) from Mexico and southern Texas (MX) were evaluated for field growth, and tolerances to soil alkalinity, drought, and foliar and soil salinity (Denny 2007; Denny et al. 2008). From these multi-location regional seedling evaluations, 24 candidate clones were subsequently evaluated for vegetative rooting potential (King 2010; King et al. 2011; King et al. 2012) and clones with adequate rooting from the initial selections were distributed to 10 sites. This encompassed sites in USDA plant hardiness zones 4b/5a to 10 (U.S. Dept. of Agriculture 1990).

Test sites included an east-west transect in USDA plant hardiness zones 8 to 10 along the U.S. Gulf Coast stretching from central Florida (Balm, FL), the Florida Panhandle (Quincy, FL), central Texas (College Station, TX), to western Texas (El Paso, TX). A north-south transect from the Gulf Coast sites through the central U.S. was located in USDA plant hardiness zones $4 \mathrm{~b} / 5 \mathrm{a}$, including northeastern Texas (Dallas, TX), the Texas panhandle (northern Texas) (Lubbock, TX), Arkansas (Fayetteville, AR), Kansas (Haysville, KS), Ohio (Columbus, $\mathrm{OH}$ ), and Iowa (Ames, IA). Each test site used a single ramet of a given clone in each of three replications. Growth (height of main trunk, trunk diameter at $15 \mathrm{~cm}$ above the soil line), foliar chlorosis (percentage of the canopy exhibiting chlorotic or necrotic foliage), and field level cold tolerance (winter survival, a qualitative rating of winter damage, and length of dieback of terminal branches) were evaluated (second-year data is presented herein, third-year is currently underway). Data from two representative clones from each of the three taxonomic groups (TD, TX, and MX) were chosen to illustrate the range of responses across environments and are presented herein.

\section{Quercus virginiana and Quercus fusiformis Complex Studies}

Acorns from four selected provenances were collected from the western range of Quercus virginiana Mill. and Quercus fusiformis Small including the Southern Texas Plains (STP), Post Oak Savannah (POS), Lake Allen Henry Dam area in the Rolling High Plains (LAH), and the Brazos River Basin (Brazos). The accession from the STP is considered to be $Q$. virginiana. The POS accession is considered to be part of the hybrid swarm (and thus a potential hybrid) of $Q$. virginiana and $Q$. fusiformis. Simpson (1988) reports trees with intermediate characteristics likely representing a hybrid swarm between $Q$. virginiana and $Q$. fusiformis where their ranges overlap. The LAH accession appears morphologically to be a hybrid of $Q$. fusiformis and the Brazos accession (Purnell 2010). Finally, the Brazos accession appeared morphologically to be a relictual population with characteristics not in keeping with any of the other accessions (Purnell 2010). These accessions were compared in various studies for taxonomy, drought tolerance, and landscape growth characteristics (Purnell 2010). Results of an acute drought experiment are presented here, in which 100 seedlings from acorns of each of the provenances were germinated in moist sand and then transplanted into $15 \mathrm{~cm}$ diameter circular pots containing a peatlite substrate (Metro-mix $200^{\mathrm{TM}}$, Sun Gro Horticulture Canada, Ltd., Vancouver, British Columbia, Canada) and amended with $4 \mathrm{~g}$ of 31-0-0 Osmocote controlled release fertilizer (Scotts; Marysville, Ohio, U.S.). Plants were then placed on a greenhouse bench and were grown under stan- dard greenhouse conditions. After establishment, the containers were placed in a randomized complete block design with a split plot arrangement with each experimental block containing one plant of each accession. The main plot was the Quercus series Virentes accession, and the split plot was the irrigation treatment. Half of the seedlings were subjected to intense drought stress by withholding all irrigation during the experiment. The remaining seedlings served as the control and were irrigated by hand to maintain plant-available soil moisture. Midday stomatal conductance readings $\left(\mathrm{g}_{\mathrm{s}}\right)$ were taken weekly using a SC-1 porometer (Decagon Devices, Inc., Pullman, Washington, U.S.). Measurements began at approximately $1200 \mathrm{HR}$ on well-exposed and fully expanded leaves. Trees with lower $\mathrm{g}_{\mathrm{s}}$ over the course of the season were assumed to be under greater stress than a tree with higher $\mathrm{g}$. A second set of plants from the same accessions were used to repeat the experiment.

\section{Landscape Establishment, Adventitious Root Growth, and Rooting Potential of Shoot Cuttings for Platanus occidentalis Provenances}

Provenance differences in establishment of $P$. occidentalis as affected by root regeneration potential were studied under field and greenhouse conditions. Four half-sib families, two from Texas and one each from Tennessee and Kentucky, U.S., were studied (Shoemake 1996; Shoemake and Arnold 1997; Shoemake et al. 2004). The Kentucky selection was a superior provenance from the Westvaco Corporation and the Tennessee provenance was a mediocre performing selection identified in the previous studies. These were chosen as superior and average comparisons. Seedlings were transplanted to containers and grown under nursery conditions and subsequently transplanted to simulated landscape plots in the field (College Station, Texas) and root observation chambers under controlled conditions in a greenhouse, as described by Shoemake and Arnold (1997) and Shoemake et al. (2004).

As a follow-up to these field studies, five $P$. occidentalis seedlings from the best performing Texas (Texas 1) and the mediocre Tennessee provenances were randomly selected from the landscape trials in the previous study. These were used as explant sources for shoot tip cuttings to determine if adventitious rooting from shoots followed similar patterns as the seedling's root regeneration potential from the same provenances. Cuttings from three developmental stages were compared in rooting percentages and various root quality measures, such as root number per cutting, root length, and dry mass. No root inducing growth regulators were applied so that rooting responses were those endogenous to the tissues. Forty cuttings from each of five seedlings (designated hereafter as clones 1 through 5) per provenance were placed in a greenhouse as softwood (late spring), semi-hardwood (mid-summer), or hardwood (dormant tissue in winter) cuttings under intermittent mist ( $6 \mathrm{sec}$. each $8 \mathrm{~min}$.) from dawn to dusk in a greenhouse on $27^{\circ} \mathrm{C}$ day $/ 21^{\circ} \mathrm{C}$ night setpoints. Cuttings were rooted in $38 \mathrm{~cm} \times 53 \mathrm{~cm} \times 10 \mathrm{~cm}$ black plastic flats (Kadon Corp., Dayton, Ohio) containing screened $(\leq 1.0 \mathrm{~cm})$ composted pine bark chips.

\section{RESULTS AND DISCUSSION}

Taxodium distichum studies. Significant $(P \leq 0.05)$ location by clone interactions were present for all measured characteristics. In many locations $T$. distichum var. mexicanum accessions grew larger than the species type or those from Texas Hill Country 
sources as can be seen with the data for MX4MD39 (Table 1). This growth advantage (Table 1) was lost in many colder winter climates (Table 2), such as Iowa, Ohio, and the Texas panhandle. Growth of all accessions was generally less at drier sites (Table 1; Table 2), such as western Texas and the Texas panhandle, even though these plantings were irrigated. This was consistent with prior reports of greater acute and chronic drought tolerance under controlled environments in accessions of $T$. distichum var. mexicanum compared to the species type (Denny 2007). In northern locations, this reduced growth may have been partly due to shorter growing seasons, but in the case of some genotypes was also due to dieback from low temperature injury (Table 3).

In previous tests, Taxodium distichum var. mexicanum and Texas Hill Country provenances have been reported to tolerate more alkaline soils than the species type (Denny 2007; Denny et al. 2008), which was consistent with a lack of foliar chlorosis development on these provenances on the western Texas site while the provenance from the species type, 477-19, had $80.0 \pm$ $9.7 \%$ of the foliage exhibiting chlorosis. However, foliar chlorosis also appeared on clones $477-19$ at the Iowa $(40.0 \pm 5.6 \%)$ and central Florida $(40.0 \pm 5.6 \%)$ sites and $492-23$ at the Iowa site $(43.3 \pm 5.6 \%)$ from eastern U.S. provenances even though the soils on these sites were acidic (Table 2). Foliar chlorosis was reported to limited extents on the $T$. $d$. var. mexicanum clones 465-23 $(15.0 \pm 5.6 \%)$ and MX4MD39 $(13.3 \pm 5.6 \%)$ grown near the Gulf Coast where foliar infection from Cercosporidium sequoiae (Ellis and Everth.) W.A. Baker and Partridge was reported to be severe with warm humid conditions. This pathogen was identified by Florida pathologists as a cause of foliar damage observed on the trees grown at the Florida sites during the study, but was not confined exclusively to a particular provenance. Trees on the Florida panhandle site were so severely infested with this pathogen during the second growing season that foliar chlorosis ratings were not attempted. Thus, the aesthetic value of taxa of Taxodium in landscapes could also be improved by selecting for greater field-level resistance to foliar pathogens such as C. sequoiae (McDonald et al. 2008).

These multistate trials with Taxodium revealed useful information related to growth and cold tolerance (Tables 1; Table 2; Table 3). While the species type $T$. distichum has been reported to be cold hardy to USDA Zone 5 or perhaps Zone $4 \mathrm{~b}$ (Flint 1983; Arnold 2008), T. d. var. mexicanum is often listed as hardy only to USDA Zone 7 (Arnold 2008). These data support the reports for the species type, but would suggest that with proper clonal selection within some provenances of $T$. $d$. var. mexicanum, it can potentially be grown in climates as cold as USDA Zone 6 (Tables 1; Table 2; Table 3). Further, the clones from alkaline soil tolerant Texas Hill Country provenances did not suffer significant dieback in Ohio or Iowa during the first two years in the field (Table 2), providing potentially cold

Table 1. Mean tree height $(\mathrm{cm})$ at the end of the second growing season in the field for selected clones of Taxodium at various United States locations in USDA plant hardiness zones $4 \mathrm{~b}$ to 10 . Clone designations: $\mathrm{MX}=$ Mexico or southern Texas, EP = Eastern Provenance, TX = Texas Hill Country; $-\mathrm{M}=T$. $d$. var. mexicanum, $-\mathrm{D}=T$. $d$. var. distichum.

\begin{tabular}{|c|c|c|c|c|c|c|c|}
\hline Location & $\begin{array}{l}\text { USDA plant } \\
\text { hardiness zone }\end{array}$ & $\begin{array}{l}\text { EP-D } \\
477-19\end{array}$ & $\begin{array}{l}\text { EP-D } \\
492-23\end{array}$ & $\begin{array}{l}\text { TX-D } \\
\text { TX8DD11 }\end{array}$ & $\begin{array}{l}\text { TX-D } \\
\text { TX8DD38 }\end{array}$ & $\begin{array}{l}\text { MX-M } \\
465-21\end{array}$ & $\begin{array}{l}\text { MX-M } \\
\text { MX4MD39 }\end{array}$ \\
\hline Iowa & $4 b$ & $88 \pm 18^{z}$ & $77 \pm 18$ & $122 \pm 18$ & $118 \pm 18$ & $100 \pm 31$ & $120 \pm 31$ \\
\hline Ohio & $5 b$ & $-y$ & $10 \pm 31$ & $68 \pm 31$ & $108 \pm 31$ & - & $98 \pm 31$ \\
\hline Kansas & $6 a$ & $125 \pm 18$ & $141 \pm 18$ & $150 \pm 18$ & $147 \pm 18$ & $148 \pm 18$ & $227 \pm 18$ \\
\hline Arkansas & $6 b$ & $120 \pm 18$ & $103 \pm 18$ & $172 \pm 18$ & $167 \pm 18$ & $130 \pm 18$ & $197 \pm 18$ \\
\hline Texas panhandle & $6 \mathrm{~b} / 7 \mathrm{a}$ & $34 \pm 18$ & $27 \pm 18$ & $46 \pm 18$ & $47 \pm 18$ & - & $50 \pm 18$ \\
\hline Northeastern Texas & $7 b$ & $85 \pm 18$ & $76 \pm 18$ & $111 \pm 18$ & $96 \pm 22$ & $121 \pm 18$ & $155 \pm 18$ \\
\hline Western Texas & $8 \mathrm{a}$ & $72 \pm 31$ & - & $128 \pm 18$ & $110 \pm 22$ & $161 \pm 22$ & $179 \pm 18$ \\
\hline Central Texas & $8 b$ & $83 \pm 31$ & $138 \pm 22$ & $113 \pm 18$ & $143 \pm 18$ & $212 \pm 18$ & $201 \pm 18$ \\
\hline Florida panhandle & $8 b$ & - & $195 \pm 22$ & $211 \pm 22$ & $150 \pm 22$ & - & $143 \pm 31$ \\
\hline Central Florida & $10 \mathrm{a} / 10 \mathrm{~b}$ & $148 \pm 18$ & $197 \pm 18$ & $210 \pm 18$ & $147 \pm 18$ & $237 \pm 18$ & $275 \pm 18$ \\
\hline
\end{tabular}

${ }^{\mathrm{z}}$ Means \pm standard errors.

y Insufficient numbers of plants were available to send all clones to all test sites; as such, a hyphen (-) indicates the a clone was not tested at a particular site, except for the Ohio location where large numbers of plants and several complete sets of individual clones were lost in the first year due to rabbit damage, thus for the Ohio data the hyphen may also indicate that no plants survived the rabbit damage.

Table 2. Location, USDA plant hardiness zone designation, winter minimum temperatures, and annual rainfall at the field trial sites (U.S.) testing clones of Taxodium distichum.

\begin{tabular}{|c|c|c|c|c|c|c|}
\hline \multirow[b]{2}{*}{ Location } & \multirow{2}{*}{$\begin{array}{l}\text { USDA plant } \\
\text { hardiness zone }\end{array}$} & \multirow[t]{2}{*}{ Soil pH } & \multicolumn{2}{|c|}{ Minimum winter temperature $\left({ }^{\circ} \mathrm{C}\right)$} & \multicolumn{2}{|c|}{ Annual precipitation $(\mathrm{cm})$} \\
\hline & & & 2009-2010 & $2010-2011$ & 2009 & 2010 \\
\hline$\overline{\text { Iowa }}$ & $4 b^{2}$ & $5.2^{y}$ & $-31.7^{x}$ & -29.4 & 94.5 & 128.5 \\
\hline Ohio & $5 b$ & 7.1 & -17.2 & -19.4 & 76.2 & 71.6 \\
\hline Kansas & $6 a$ & 6.3 & -17.2 & -20.0 & 104.9 & 63.8 \\
\hline Arkansas & $6 \mathrm{~b}$ & 5.6 & -12.2 & -11.7 & 127.0 & 106.7 \\
\hline Texas panhandle & $6 \mathrm{~b} / 7 \mathrm{a}$ & 8.2 & -15.0 & -16.7 & 32.8 & 67.3 \\
\hline Northeastern Texas & $7 b$ & 7.7 & -10.0 & -11.1 & 100.6 & 74.4 \\
\hline Western Texas & $8 \mathrm{a}$ & 8.4 & -6.1 & -5.2 & 16.5 & 33.0 \\
\hline Central Texas & $8 \mathrm{~b}$ & 7.1 & -8.0 & -7.0 & 99.1 & 70.6 \\
\hline Florida panhandle & $8 \mathrm{~b}$ & 5.3 & -9.4 & -6.1 & 169.9 & 110.7 \\
\hline Central Florida & $10 \mathrm{a} / 10 \mathrm{~b}$ & 5.9 & -2.2 & 0.0 & 79.8 & 53.3 \\
\hline
\end{tabular}

${ }^{\mathrm{z}}$ As indicated in the 1990 USDA Plant Hardiness Zone map.

${ }^{y}$ Mean of three samples per location.

${ }^{x}$ Temperature and precipitation data either recorded on site, or if unavailable on site was estimated using the nearest official weather station. 
Table 3. Mean dieback of terminal branches $(\mathrm{cm})$ after second winter in the field for selected clones of Taxodium at various locations (U.S.) in USDA plant hardiness zones $4 \mathrm{~b}$ to 10 , temperatures at the lowa location reached $-31.7^{\circ} \mathrm{C}$. Clone designations: $\mathrm{MX}=$ Mexico or southern Texas, $\mathrm{EP}=$ Eastern Provenance, $\mathrm{TX}=$ Texas Hill Country; $-\mathrm{M}=T$. $d$. var. mexicanum, $-\mathrm{D}=T$. $d$. var. distichum.

\begin{tabular}{|c|c|c|c|c|c|c|c|}
\hline Location & $\begin{array}{l}\text { USDA plant } \\
\text { hardiness zone }\end{array}$ & $\begin{array}{l}\text { EP-D } \\
477-19\end{array}$ & $\begin{array}{l}\text { EP-D } \\
492-23\end{array}$ & $\begin{array}{l}\text { TX-D } \\
\text { TX8DD11 }\end{array}$ & $\begin{array}{l}\text { TX-D } \\
\text { TX8DD38 }\end{array}$ & $\begin{array}{l}\text { MX-M } \\
465-21\end{array}$ & $\begin{array}{l}\text { MX-M } \\
\text { MX4MD39 }\end{array}$ \\
\hline Iowa & $4 b$ & $1 \pm 6.0^{z}$ & $0 \pm 6.0$ & $0 \pm 6.0$ & $2 \pm 6.0$ & $62 \pm 7.4$ & $58 \pm 10.4$ \\
\hline Ohio & $5 b$ & $-y$ & $51 \pm 7.4$ & $0 \pm 10.4$ & $0 \pm 10.4$ & $39 \pm 10.4$ & $44 \pm 7.4$ \\
\hline Arkansas & $6 b$ & $0 \pm 6.0$ & $0 \pm 6.0$ & $0 \pm 6.0$ & $0 \pm 6.0$ & $5 \pm 6.0$ & $0 \pm 6.0$ \\
\hline Texas panhandle & $6 \mathrm{~b} / 7 \mathrm{a}$ & $8 \pm 6.0$ & $7 \pm 6.0$ & $22 \pm 6.0$ & $4 \pm 6.0$ & - & $4 \pm 6.0$ \\
\hline Northeastern Texas & $7 b$ & $0 \pm 6.0$ & $0 \pm 6.0$ & $0 \pm 6.0$ & $0 \pm 7.4$ & $0 \pm 6.0$ & $0 \pm 6.0$ \\
\hline Western Texas & $8 \mathrm{a}$ & $3 \pm 10.4$ & - & $1 \pm 6.0$ & $2 \pm 7.4$ & $2 \pm 7.4$ & $3 \pm 6.0$ \\
\hline Florida panhandle & $8 b$ & - & - & - & - & - & - \\
\hline Central Florida & $10 \mathrm{a} / 10 \mathrm{~b}$ & $0 \pm 6.0$ & $0 \pm 6.0$ & $0 \pm 6.0$ & $0 \pm 6.0$ & $0 \pm 6.0$ & $0 \pm 6.0$ \\
\hline
\end{tabular}

${ }^{z}$ Values indicate means + standard errors.

${ }^{y}$ Insufficient numbers of plants were available to send all clones to all test sites; as such, a hyphen (-) indicates the clone was not tested at a particular site, except for the Ohio location where large numbers of plants and several complete sets of individual clones were lost in the first year due to rabbit damage, thus for the Ohio data the hyphen may also indicate that no plants survived the rabbit damage. Dieback measures were not reported for the Florida panhandle site.

hardy selections with tolerance to alkaline soils. Longer term data is needed to substantiate these initial findings. Furthermore, Texas Hill Country provenances were previously shown to be intermediate in drought and foliar salinity tolerance between the Mexican/southern Texas provenances and those of the species type from eastern provenances (Denny 2007). Denny (2007) found that some physiological traits-such as tolerances to soil alkalinity, water deficit, and foliar salt exposure - and growth rates exhibited mostly discontinuous regional geographic components, whereas other traits, for instance soil salinity tolerance, appeared to be expressed as racial traits associated with localized families rather than regional populations.

\section{Quercus virginiana and Quercus fusiformis Complex Studies}

The Virentes series individuals with the highest levels of $g_{s}$, when irrigation was not withheld, was the Brazos River Basin accession. The LAH accession appeared to be a possible cross of the Brazos accession and Q. fusiformis (Purnell 2010). The LAH accession did not differ in $\mathrm{g}_{\mathrm{s}}$ in response to irrigation (Figure 1). These accessions are both in areas typically receiving less than $46 \mathrm{~cm}$ rainfall per year. Anecdotal reports contend that $Q$. fusiformis has greater drought resistance than Q. virginiana (Garrett 1996; Wasowski and Wasowski 1997; Arnold 2008). Experimental work reported by Purnell (2010) is consistent with this contention. The accession from the greater rainfall area (STP) had the numerically lowest $g_{s}$, significantly so in comparison to the LAH Dam accession (Figure 1). Abrams (1990) indicated differential leaf conductance was found during water deficits when comparing oaks from xeric and mesic habitats. He explained that in the Missouri pygmy oak forest, blackjack oak (Quercus marilandica Muench) stomata closure occurs later than in northern red oak (Quercus rubra L.) during periods of both moderate and peak drought. From these results, it may be concluded the Virentes accessions are adaptable to different moisture regions. The Brazos, $\mathrm{LAH}$, and POS accessions may provide some improvement in drought resistance for adverse locations while maintaining other desirable traits. Under irrigated conditions, the Brazos accession had greater $g_{s}$ than the other accessions (Figure 1).

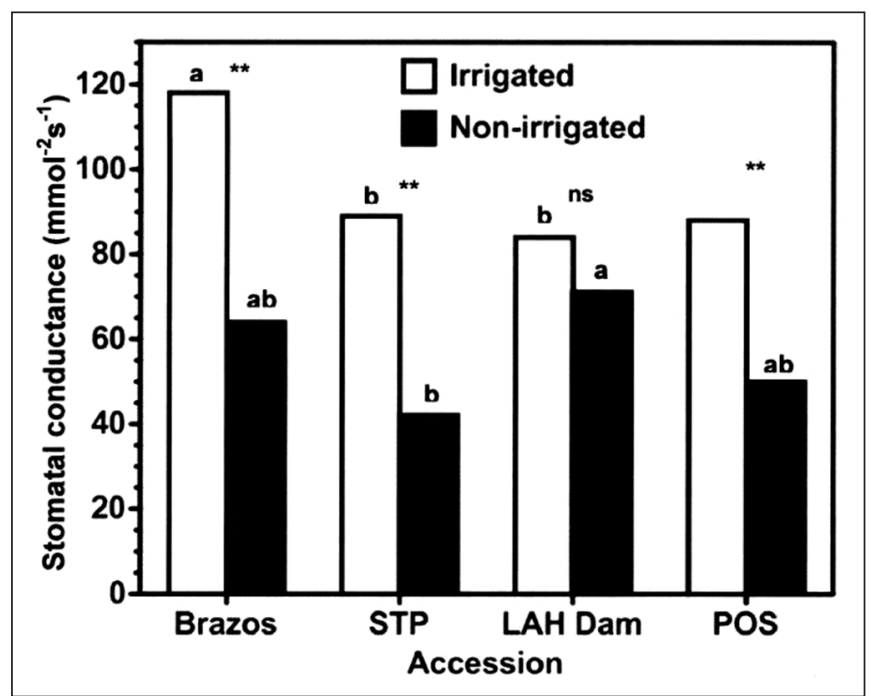

Figure 1. Spring $2009 \mathrm{~g}_{\mathrm{s}}$ of Quercus series Virentes accessions with and without irrigation. Accessions included Southern Texas Plains (STP), Post Oak Savannah (POS), Lake Allen Henry Dam area in the Rolling High Plains (LAH), and Brazos River Basin (Brazos) in Texas. Columns within the same drought treatment followed by the same letter are not statistically different at $P \leq$ 0.05 . Asterisks $\left({ }^{* *}\right)$ indicate that the responses of irrigated and non-irrigated treatments for an accession differed at $P \leq 0.05$; $\mathrm{ns}=$ not significant between irrigated or non-irrigated within the accession; $\mathbf{n}=100$.

\section{Landscape Establishment, Adventitious Root Growth, and Rooting Potential of Shoot Cuttings for Platanus occidentalis Provenances}

Previous work (Shoemake 1996; Shoemake and Arnold 1997) had demonstrated that Texas regional provenances of Platanus occidentalis grew $25 \%$ to $50 \%$ more than distant provenances from Kentucky and Tennessee during the first three years when grown in central Texas, and that these field responses corresponded with the provenances' differences in root regeneration potentials as measured in controlled conditions in the greenhouse. Texas provenances regenerated roots two to three times more rapidly during the first two weeks immediately after trans- 
planting than did the more northern Kentucky and Tennessee provenances (Arnold et al. 1998), suggesting the potential importance of initial root regeneration responses in differential establishment and growth among provenances. This would also suggest the possibility of selecting among provenances and clones within provenances for improved landscape establishment traits, such as rapid root regeneration potential, to produce landscape trees that generate a new root system more quickly, minimizing transplant losses. Ware (1980) suggested that native bottomland species may contain genotypes tolerant of current urban soil challenges, such as more poorly drained clays. Assessing root regeneration potentials, either in the field or in controlled environments, can be tedious and time consuming (Bohm 1979).

Thus, since many of the same hormonal factors control adventitious root regeneration from both root and shoot tissues, it could be advantageous if adventitious root regeneration capacities that are important in transplant establishment followed similar patterns among genotypes as more easily assessed traits, such as adventitious rooting of shoot tip cuttings. To that end, the rooting of shoot tips at various stages of maturation from five seedlings of a provenance shown (Shoemake et al. 2004) to have a high level of root regeneration capacity (Texas 1) and shoot tip cuttings from five seedlings of a provenance with a lower level of root regeneration capacity (Tennessee) were compared. Adventitious rooting from shoot cuttings in terms of rooting quantity measures, such as percent of cuttings that rooted, was greatest for both provenances with semi-hardwood cuttings (Figure 2A). Shoots from Texas 1 seedlings rooted similarly at the softwood and semi-hardwood stages, while softwood shoots from some of the Tennessee ramets did not root as well as those from semi-hardwood cuttings (Figure 2A). Shoots from all seedlings of both provenances, except Tennessee clone 5, rooted in much fewer numbers from hardwood cuttings (Figure 2A). This is in contrast to reports by Vlachov (1988), who reported winter rooting (hardwood cuttings) to yield optimal rooting percentages on three species of Platanus L. Root system quality measures, including the number of roots regenerated per cutting (Figure 2B) or the elongation of those roots after initiation (Figure 2C), were greatest on semi-hardwood cuttings, intermediate on softwood cuttings, and typically lower on hardwood cuttings. Neither the quantity of shoots that rooted (Figure $2 \mathrm{~A}$ ), nor the root system quality measures (Figure 2B; Figure $2 \mathrm{C}$ ) followed the same pattern of responses with regard to provenances as was observed with root regeneration from root tissues (Shoemake et al. 2004). Thus, these data would not support the use of this trait as a predictor of rapid determination of new root growth potential from root tissue. However, this study used only a small sample of five seedlings from each of the two provenances and a larger sample size would be needed to provide more conclusive evidence. What this study did confirm was the importance that the range in ability of seedlings within a provenance to adventitiously produce roots from shoot cuttings would play in any effort to capture gains in broad sense heritability via vegetative propagation of superior clones within seedlings from a given provenance. Substantial variability in rooting measures was present at each developmental stage of shoot maturation among the clones of each provenance (Figure 2). The greatest degree of variation was present with the hardwood cuttings, in which as large as ten-fold differences in adventitious rooting potential were present among clones of the same provenance at the same stage of shoot maturation (Figure 2). This is consistent with reports of a high

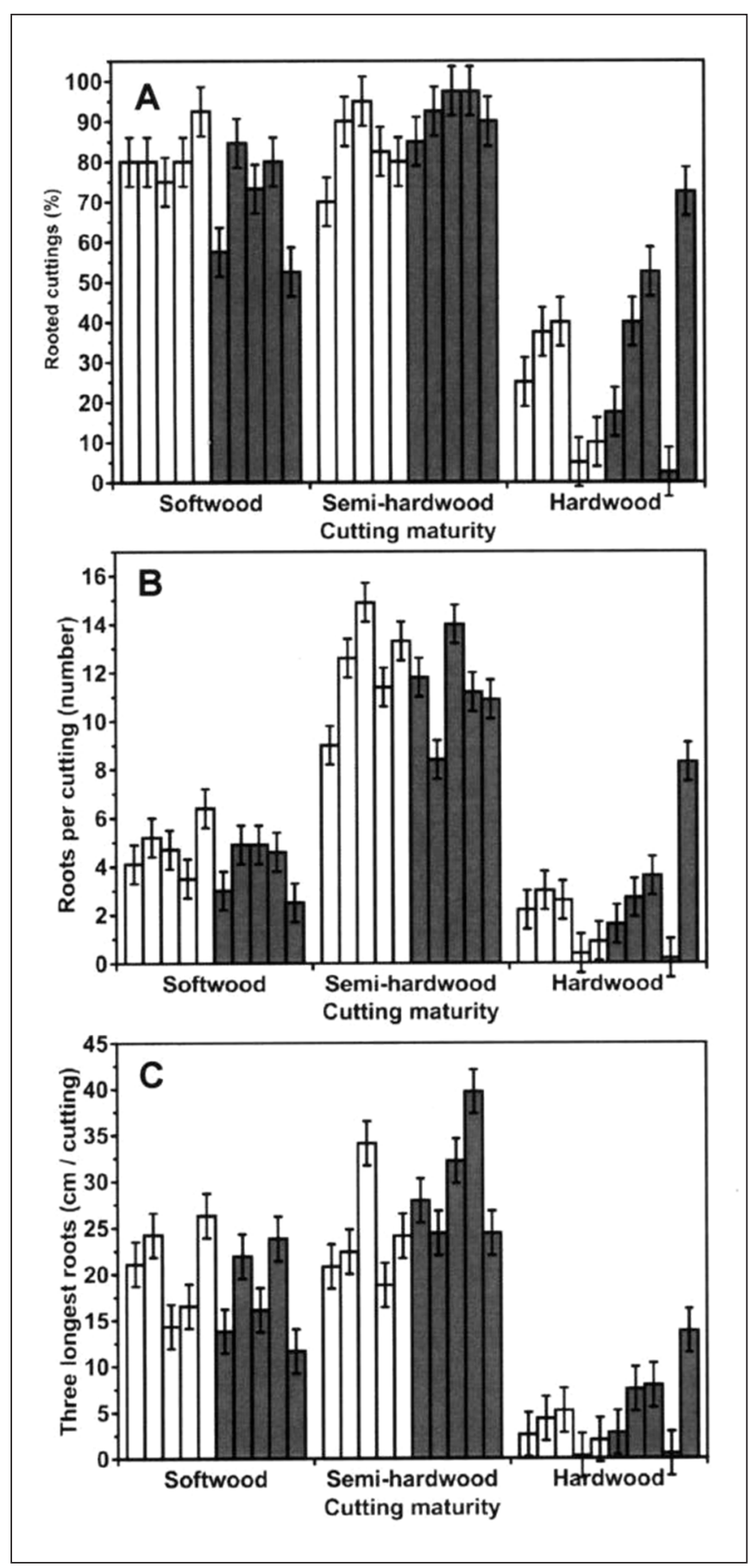

Figure 2. Variation in (A) adventitious rooting percentages, (B) adventitious root number per shoot tip cutting, and (C) the length of the five longest regenerated roots of selected clones (ramets) within seedling populations of Platanus occidentalis provenances Texas 1 and Tennessee; columns represent means ( \pm standard errors) from four replicate blocks of ten cuttings in each replicate block taken at softwood, semi-hardwood, and hardwood developmental stages. Within a developmental stage, Texas 1 cuttings are indicated on the left with clear columns 1 through 5 , respectively, for each clone (left to right), and Tennessee cuttings are indicated on the right side with shaded columns 1 through 5 , respectively, for each clone (left to right). 
degree of variation in rooting potential of stem cuttings from $\mathrm{F}_{1}$ hybrids between P. occidentalis and Platanus orientalis L. (Panetsos et al. 1994). Similar wide variation in adventitious rooting of Taxodium shoot tip cuttings has been reported within provenances that would impact the potential to capture gains in broad sense heritability for other traits (King 2010; King et al. 2012).

\section{CONCLUSIONS}

Evidence presented herein confirms the potential to improve narrow sense heritability improvements in the growth and aesthetic qualities of landscape trees by selection of proper provenances that grow larger, faster once established and possess a range of urban stress tolerance traits. Further gains may be obtained in broad sense heritability where vegetative propagation is possible, but it will be critical to elucidate clonal propagation/production methods to obtain these additional gains as the ability to adventitiously root from shoot tissues does not appear to be associated directly with improved growth traits. Work discussed herein demonstrates the potential for not only the selection of growth rates or aesthetic traits using provenance studies, but also inclusion of adaptive traits in cultivar selection that would result in a better adapted urban forest. In the United Kingdom, provenance recommendations have been issued by the Forestry Commission (Hubert and Cundall 2006) for some species. The development of similar recommendations on a regional basis for the urban forest would be useful in urban forest management in the United States.

In addition to the work presented herein, preliminary screening for tolerance in provenances of Taxodium to Cercosporidium sequoiae infection (McDonald et al. 2008), chronic and acute drought tolerance (Denny 2007), foliar and soil salinity exposure (Denny 2007), and alkalinity tolerance (Denny et al. 2008) have been completed. Studies to assess genotypic differences in response to flooding, resulting in differential soil oxygen levels, are underway in the hopes that a relationship with knee development can be identified permitting selection of genotypes with reduced knee development. Effects of branching angles of ortets on propagation of ramets and potential topophytic responses associated with provenance are also being investigated (King 2010). Methods of provenance evaluations discussed here are also being extended to the development of regionally adapted groundcovers and shrubs from native North American species for built environments.

Acknowledgments. This project was funded in part by Texas AgriLife Research (formerly the Texas Agricultural Experiment Station) and grants from the Tree Research \& Education Endowment Fund and the J. Frank Schmidt Family Charitable Trust. Mention of a trademark, proprietary product, or vendor does not constitute a guarantee or warranty of the product by the authors, Texas A\&M University, Texas AgriLife Research, or other involved institutions, and does not imply its approval to the exclusion of other products or vendors that also may be suitable.

\section{LITERATURE CITED}

Abrams, M.D. 1990. Adaptations and responses to drought in Quercus species of North America. Tree Physiology 7:227-238.

Arnold, M.A. 2008. Landscape Plants for Texas and Environs, Third Edition. Stipes Publishing, L.L.C., Champaign, Illinois, U.S. 1334 pp.

Arnold, M.A. 2011. Providence provides provenances for proper plants. Nursery Management 27(9):46-49

Arnold, M.A., L.J. Shoemake, and M.W. Goyne. 1998. Seed selection and nursery production practices impact root regeneration and tree establishment. pp. 13-26. In: The Landscape Below Ground II. Proc. of a Second Intl. Workshop on Tree Root Development in Urban Soils. Intl. Soc. of Arboriculture, Champaign, Illinois, U.S.

Bohm, W. 1979. Methods of Studying Root Systems. Springer-Verlag, New York, New York, U.S.. 188 pp.

Bsoul, E., R. St. Hilaire, and D.M. VanLeeunwen. 2007. Bigtooth maples from selected provenances effectively endure deficit irrigation. HortScience 42:1167-1173.

Denny, G.C. 2007. Evaluation of selected provenances of Taxodium distichum for drought, alkalinity, and salinity tolerance. Ph.D. Dissertation, Texas A\&M Univ., College Station, Texas, U.S. 142 pp.

Denny, G.C., M.A. Arnold, and W.A. Mackay. 2008. Evaluation of alkalinity tolerance of selected provenances of Taxodium Rich. HortScience 43:1987-1900.

Flint, H.L. 1983. Landscape Plants for Eastern North America: Exclusive of Florida and the Immediate Gulf Coast. John Wiley and Sons, New York, New York, U.S. 677 pp.

Garrett, H. 1996. Howard Garrett's Plants for Texas. Univ Texas Press, Austin, Texas, U.S. 170 pp.

Graves, W.R. 1996. Drought resistance in trees: an overview of mechanisms and new research with Iowa's black maples. In: METRIA 9: Proc. of the Ninth Metropolitan Tree Improvement Alliance Conf. Accessed04/02/2012.<www.ces.ncsu.edu/fletcher/programs/nursery/ metria/metria09/graves.html>

Guries, R.P., and E.B. Smalley. 1990. Selecting and testing elms: the Wisconsin elm breeding program. pp. 21-30. In: METRIA 7: Trees for the Ninties: Landscape Tree Selection, Testing, Evaluation, and Introduction, Proc. of the Seventh Conf. of the Metropolitan Tree Improvement Alliance. Accessed 04/02/2012. <www.ces.ncsu.edu/ fletcher/programs/nursery/metria/metria07/m74.pdf>

Houston, D. 1988. The importance of seed source to tree planting in the urban forest. pp. 67-79. In: METRIA 6: Selecting and Preparing Sites for Urban Trees. Proc. of the Fifth Conf. of the Metropolitan Tree Improvement Alliance. Accessed 04/02/2012. <www.ces.ncsu.edu/ fletcher/programs/nursery/metria/metria06/m67.pdf>

Hubert, J., and E. Cundall. 2006. Choosing provenance in broadleaved trees. Forestry Commission, Edinburgh, UK. 12 pp.

King, A.R. 2010. Vegetative propagation and topophytic responses of selected baldcypress clones. M.S. Thesis, Texas A\&M University, College Station, Texas, U.S. 96 pp.

King, A.R., M.A. Arnold, D.F. Welsh, and W.T. Watson. 2011. Substrates, wounding, and growth regulator concentrations alter adventitious rooting of baldcypress cuttings. HortScience 46:1387-1393.

King, A.R., M.A. Arnold, D.F. Welsh, and W.T. Watson. 2012. Developmental stage and growth regulator concentration differentially affect vegetative propagation of select clones of Taxodium Rich. HortScience 47:1-11.

Kriebel, H.B., and C.-W. Wang. 1962. The interaction between provenance and degree of chilling in bud-break of sugar maple. Silvae Genetica 11:125-130. 
McDonald, G.V., G.C. Denny, M.A. Arnold, L.W. Barnes, and D.L. Bryan. 2008. Comparative canopy damage among provenances of baldcypress associated with the presence of Cercosporidium sequoiae (Ellis and Everth.) W.A. Baker and Partridge. HortScience 43(6): 1703-1705.

Pai, J.G.B., and W.R. Graves. 1995. Influence of inoculant form and applied nitrogen on growth and root nodulation of Maackia amurensis. Journal of Environmental Horticulture 13:40-42.

Pair, J.C. 1994. Selecting tatter and scorch resistant sugar maples. pp. 98-100. In: METRIA 8: Plant Exploration, Tree Physiology, Breeding and Selection in Crabapples, Elms, Dogwoods, Oaks and Maples. Proc. of the Eight Conf. of the Metropolitan Tree Improvement Alliance. Accessed 04/02/2012. <www.ces.ncsu.edu/fletcher/programs/ nursery/metria/metria08/m813.pdf>

Panetsos, K.P., A.V. Scaltsoyiannes, and P.G. Alizoti. 1994. Vegetative propagation of Platanus orientalis $\times P$. occidentalis $\mathrm{F}_{1}$ hybrids by stem cuttings. Forest Genetics 1(3):125-130.

Pounders, C., D.C. Fare, and C. Cheatham. 2004. Provenance and production location affects growth and quality of Quercus phellos $\mathrm{L}$. and Q. shumardii Buckl. seedlings. Journal of Environmental Horticulture 22:202-208.

Purnell, A.L. 2010. Determination of drought tolerance and heredity of Quercus series Viretes in Texas. Specifically, Quercus virginiana and Quercus fusiformis accessions for adaptation to demanding environments. M.S. Thesis, Texas Tech Univ., Lubbock, Texas, U.S. 63 pp.

Schrader, J.A., and W.R. Graves. 2000. Seed germination and seedling growth of Alnus maritima from its three disjunct populations. Journal of the American Society for Horticultural Science 125:128-134.

Shoemake, L.J. 1996. The effects of mother tree selection on the root regeneration potential of container-grown sycamore (Platanus occidentalis L.). M.S. Thesis, Texas A\&M Univ. College Station, Texas, U.S. 83 pp.

Shoemake, L.J., and M.A. Arnold. 1997. Half-sib family selection improves container nursery and post-transplant landscape performance of sycamore. Journal of Environmental Horticulture 15:126-130.

Shoemake, L.J., M.A. Arnold, and F.T. Davies, Jr. 2004. Provenance impacts transplant establishment and adventitious root regeneration of sycamore. Journal of the American Society for Horticultural Science 129:360-367.

Sibley, J.L, D.J. Eakes, C.H. Gilliam, G.J. Keever, and W.A. Dozier, Jr. 1995. Growth and fall color of red maple selections in the southeastern United States. Journal of Environmental Horticulture 13:51-53.

Sibley, J.L., D.J. Eakes, C.H. Gilliam, G.J. Keever, and W.A. Dozier, Jr. 1997. Photosynthetic response of selected red maple cultivars to light. Journal of Arboriculture 23:100-105.

Simpson, B.J. 1988. A Field Guide to Texas Trees. Texas Monthly Press, Austin, Texas, U.S. 372 pp.

St. Hilaire, R., and W.R. Graves. 2001. Stability of provenance differences during development of hard maple seedlings irrigated at two frequencies. HortScience 36:654-657.

Struve, D.K., and S.E. McKeand. 1994. Importance of red oak mother tree to nursery productivity. Journal of Environmental Horticulture 12:23-26.

Struve, D.K. 1982. Breeding for tree improvement requires industry cooperation. American Nurseryman July 1, 1982. pp. 179-181.

Struve, D.K., P. Sternberg, N. Drunasky, K. Bresko, and R. Gonzalez. 2006. Growth and water use characteristics of six eastern North American oak (Quercus) species and the implications for urban forestry. Arboriculture \& Urban Forestry 32:202-213.
Townsend, A.M. 1977. Characteristics of red maple progenies from different geographic areas. Journal of the American Society for Horticultural Science 102:461-466.

Townsend, A.M. 1983. Genetic potential of red maple for urban use. pp. 34-42. In: METRIA 4: New Trees for Metropolitan Landscapes: The METRIA Species Trials Project, Proc. of the Fourth Metropolitan Tree Alliance. Accessed 04/02/2012. <www.ces.ncsu.edu/fletcher/ programs/nursery/metria/metria04/m46.pdf>

United States Department of Agriculture. 1990. USDA Plant Hardiness Zone Map. U.S. Dept. Agric./Agric. Res. Ser. Misc. Publ. No. 1475.

Vlachov, D.D. 1988. Vegetative propagation of sp. Platanus L. through rooting of cuttings. Acta Horticulturae 226:375-378.

Ware, G.H. 1980. Selecting trees for clay soils. pp. 102-106. In: METRIA 3: Urban Trees and Their Soils, Proc. of the Third Conf. of the Metropolitan Tree Improvement Alliance. Accessed 04/02/2012. $<$ http://www.ces.ncsu.edu/fletcher/programs/nursery/metria/ metria03/>

Ware, G.H. 1983. Acer saccharum subspecies nigrum: meritorious Midwestern maple. pp. 1-6. In: METRIA 4: New Trees for Metropolitan Landscapes: The METRIA Species Trials Project, Proc. of the Fourth Metropolitan Tree Alliance. Accessed 04/02/2012. <www.ces.ncsu. edu/fletcher/programs/nursery/metria/metria04/>

Wasowski, S., and A. Wasowski. 1997. Native Texas Plants Landscaping Region By Region, Sec. Ed. Gulf Publishing Co., Houston, Texas, U.S. 407 pp.

Zhou, L. 2005. Salt tolerance, propagation, and provenance evaluation of Taxodium as a landscape and coastal wetland tree. M.S. Thesis, Stephen F. Austin State Univ., Nacogdoches, Texas, U.S. 61 pp.

Zobel, B., and J. Talbert. 1984. Applied Forest Tree Improvement. John Wiley and Sons, New York, New York, U.S. 505 pp.

Zobel, B.J., G. Van Wyk, and P. Stahl. 1987. Growing Exotic Forests. John Wiley and Sons, New York, New York, U.S. 508 pp.

Zwack, J.A., W.R. Graves, and A.M. Townsend. 1998. Leaf water relations and plant development of three Freeman maple cultivars subjected to drought. Journal of the American Society of Horticultural Science 123:371-375.

Michael A. Arnold (corresponding author)

Professor

Texas A\&M University

Department of Horticultural Sciences

2133 TAMU

College Station, TX 77843-2133, U.S.

ma-arnold@tamu.edu

Donita L. Bryan

Assistant Professor

University of Wisconsin - Platteville

1 University Plaza

Platteville, WI 53818, U.S.

Raul I. Cabrera

Associate Professor

Texas AgriLife Research and Extension Center at Dallas

17360 Coit Road

Dallas, TX 75252, U.S. 
Geoffrey C. Denny

G.C. Denny Horticulture

12905 County Road 675

Parrish, FL 34219, U.S.

Jason J. Griffin

Associate Professor and Director

John C. Pair Horticultural Center - Wichita

Kansas State University

1901 E 95th St. S.

Haysville, KS 67060, U.S.

Jeffery K. Iles

Professor and Chair

Department of Horticulture

Iowa State University

106 Horticulture Hall

Ames, IA 50011-1100, U.S.

Andrew R. King

Research Associate

Department of Horticultural Sciences

Texas A\&M University

2133 TAMU

College Station, TX 77843-2133, U.S.

Gary W. Knox

Professor

University of Florida

North Florida Research and Education Center

155 Research Road

Quincy, FL 32351-5677, U.S.

Leonardo Lombardini

Associate Professor

Department of Horticultural Sciences

Texas A\&M University

2133 TAMU

College Station, TX 77843-2133, U.S.

Garry V. McDonald

Assistant Professor

Department of Horticulture

316 Plant Science Building

University of Arkansas

Fayetteville, AR 72701, U.S.

Cynthia B. McKenney

Professor

Department of Plant and Soil Science

Texas Tech University

15th and Detroit, Room 105, Mail Stop 2122

Lubbock, TX 79409-2122, U.S.
D. Thayne Montague

Associate Professor

Department of Plant and Soil Science

Texas Tech University

15th and Detroit, Room 105, Mail Stop 2122

Lubbock, TX 79409-2122, U.S.

Genhua Niu

Associate Professor

Texas AgriLife Research Center at El Paso

1380 A\& M Circle

El Paso, TX 79927, U.S.

H. Brent Pemberton

Professor

Texas AgriLife Research and Extension Center at Overton

P.O. Box 200

Overton, TX 75684, U.S.

Adam L. Purnell

Former Graduate Student

Department of Plant and Soil Science

Texas Tech University

15th and Detroit, Room 105, Mail Stop 2122

Lubbock, TX 79409-2122, U.S.

Larry J. Shoemake

Former Graduate Research Associate

Department of Horticultural Sciences

Texas A\&M University

2133 TAMU

College Station, TX 77843-2133, U.S.

Daniel K. Struve

Professor

Department of Horticulture and Crop Science

The Ohio State University

241 B Howlett Hall, 2001 Fyffe Court

Columbus, $\mathrm{OH} 43210$, U.S.

W. Todd Watson

Adjunct Professor

Department of Ecosystem Science and Management

Texas A\&M University

2138 TAMU

College Station, TX 77843-2138, U.S. 
Résumé. Les variations écotypique, clonale et raciale présentent parmi les espèces d'arbres au sein de leur diversité d'habitats naturels représentent une vaste opportunité peu explorée pour sélectionner des sources de semences ou du matériel clonal afin de composer avec la variété unique de stress environnementaux imposés dans les milieux construits et les territoires aménagés. Cet article met l'accent sur trois genres importants de plantes ligneuses (Quercus L., Platanus L. et Taxodium Rich.) et les efforts de recherches pour découvrir des génotypes supérieurs avec des tolérances aux stress environnementaux, incluant les conditions de sols alcalins, les déficits en humidité et les températures extrêmes. Les auteurs de cette étude se sont aussi intéressés à l'exploitation géographique des provenances et à la sélection de familles obtenues par pollinisation libre afin d'identifier des génotypes ou des populations uniques qui ont des attributs ornementaux désirables, un potentiel de croissance rapide des racines et/ou une architecture végétale désirable. Une discussion est présentée sur les résultats courants, les impacts potentiels de la sélection d'arbres forestiers urbains pour des sites aménagés ainsi que sur les plans de développements futurs.

Zusammenfassung. Die Präsenz von ökotypischen, klonalen und rassischen Variationen in Baumarten innerhalb ihrer nativen Verbreitung stellen eine größtenteils ungenutzte Gelegenheit zur Selektion von Superior-Saat-Quellen oder Klon-Material, welches einer Vielzahl von einzigartigen, umweltbedingten Stressfaktoren in gestalteten Umfeldern und Landschaften trotzen muss, dar. Diese Studie fokussiert auf drei wichtigen holzartigen Pflanzengenera (Quercus L., Platanus L., und Taxodium Rich.) und den Bemühungen der Forscher anspruchsvolle Genotypen mit Toleranz gegenüber Umweltbedingten Stressfaktoren, einschließlich alkaliner Bodenbedingungen, Feuchtigkeitsdefizit und extremer Temperaturschwankungen, zu entdecken. Die Autoren dieser Studie sind auch interessiert, geografische Herkünfte und Familien mit offener Befruchtung zu selektieren, um einzigartige Genotypen oder Populationen zu identifizieren, die wünschenswerte ornamentale Attribute, rasches Wurzelwachstumspotential und/oder eine wünschenswerte Pflanzenarchitektur auf sich vereinigen. Eine Diskussion der gegenwärtigen Ergebnisse, potentieller Einflüsse auf die Selektion urbaner Forstbaumarten in gestalteten Landschaftsräumen und Pläne für eine künftige Entwicklung und Forschung werden hier präsentiert.

Resumen. La variación ecotípica clonal y racial presente en especies de árboles a través de sus rangos nativos representan una oportunidad en gran medida sin explotar para seleccionar fuentes de semilla superior o material clonal para soportar una variedad de tensiones ambientales únicas impuestas en entornos construidos y paisajes manejados. Este documento se centra en tres géneros de las más importantes plantas leñosas (Quercus L., Platanus L. y Taxodium Rich) y los esfuerzos de los investigadores para descubrir genotipos superiores con tolerancias a tensiones ambientales, incluyendo condiciones de suelos alcalinos, déficits de humedad y temperaturas extremas. Los autores del estudio también están interesados en la explotación de procedencias geográficas y selección de familias de polinización abierta para identificar genotipos únicos o poblaciones con atributos deseables como ornamentales, potencial de regeneración rápida de raíz o arquitectura de plantas deseables. Se presenta una discusión de los resultados actuales, impactos potenciales en la selección de árboles del bosque urbano para paisajes administrados y planes para el futuro desarrollo e investigación. 